\title{
Oral Health in Brazil - Part II: Dental Specialty Centers (CEOs)
}

\author{
Vinícius Pedrazzi(a) \\ Katia Regina Hostilio Cervantes \\ Dias $^{(b)}$ \\ Sigmar de Mello Rode(c)
}

(a) $\mathrm{PhD}$, Associate Professor, Department of Dental Materials and Prosthodontics, School of Dentistry of Ribeirão Preto, University of São Paulo, Ribeirão Preto, SP, Brazil.

(b) PhD, Chair Professor, Department of Restorative Dentistry, State University of Rio de Janeiro, Rio de Janeiro, RJ, Brazil.

(c) PhD, Adjunct Professor, Department of Dental Materials and Prosthodontics, School of Dentistry of São José dos Campos, São Paulo State University, São José dos Campos, SP, Brazil.

\author{
Corresponding author: \\ Vinícius Pedrazzi \\ Universidade de São Paulo \\ Faculdade de Odontologia de Ribeirão Preto \\ Departamento de Materiais Dentários \\ e Prótese \\ Av. do Café, $s / n^{\circ}$, Monte Alegre \\ Ribeirão Preto - SP - Brasil \\ CEP: 14040-904 \\ E-mail: pedrazzi@forp.usp.br
}

Received for publication on Jun 10, 2008

Accepted for publication on Jul 08, 2008

\begin{abstract}
The concepts of health promotion, self-care and community participation emerged during the 1970s and, since then, their application has grown rapidly in the developed world, showing evidence of effectiveness. In spite of this, a major part of the population in the developing countries still has no access to specialized dental care such as endodontic treatment, dental care for patients with special needs, minor oral surgery, periodontal treatment and oral diagnosis. This review focuses on a program of the Brazilian Federal Government named CEOs (Dental Specialty Centers), which is an attempt to solve the dental care deficit of a population that is suffering from oral diseases and whose oral health care needs have not been addressed by the regular programs offered by the SUS (Unified National Health System). Literature published from 2000 to the present day, using electronic searches by Medline, Scielo, Google and hand-searching was considered. The descriptors used were Brazil, Oral health, Health policy, Health programs, and Dental Specialty Centers. There are currently 640 CEOs in Brazil, distributed in 545 municipal districts, carrying out dental procedures with major complexity. Based on this data, it was possible to conclude that public actions on oral health must involve both preventive and curative procedures aiming to minimize the oral health distortions still prevailing in developing countries like Brazil.
\end{abstract}

Descriptors: Brazil; Oral health; Health policy; Program development; Dental Specialty Centers; Health program and project evaluation. 


\section{Disclosures}

This article was sponsored by an educational grant from Johnson \& Johnson do Brasil Indústria e Comércio para Saúde Ltda.

\section{Introduction}

Health is a state of complete physical, mental and social well-being and not merely the absence of disease or infirmity. This concept is current, and means that an individual has to feel well in several ways to be considered healthy. ${ }^{1}$

Nowadays, caries and periodontal disease are, more clearly than ever, viewed as infectious diseases processes. Thus, a medical model of treatment and non-restorative approaches have been advocated, including, on one hand, caries control measures and remineralization methods for initial lesions, and on the other, scaling and root planing (SRP) and the employment of some therapeutic agents like mouthwashes. ${ }^{1,2}$

The concepts of health promotion, self-care and community participation emerged during the 1970s, primarily out of concerns regarding the limitations of professional health systems. Since then, there has been a rapid growth in these areas in the developed world, showing evidence of effectiveness of such interventions, according to Bhuyan ${ }^{3}$ (2004). These areas are still at an early stage in the developing countries. There is a window of opportunity for promoting self-care and community participation for health promotion. ${ }^{3}$

This study is a sequel to the previous article "Oral Health in Brazil - Part I: Public Oral Health Policies". The aim of this literature review is to present the Dental Specialty Centers (CEOs), an alternative to complement the preventive programs developed by the Brazilian government that includes more specific and more complex dental care procedures.

To this end, Brazilian government data and literature published from 1929 to the present day were considered, using electronic searches by Medline, Google and hand-searching. The descriptors used were Brazil, Oral health, Health policy, Health programs, and Dental Specialty Centers.

\section{Dental Specialty Centers (CEOs)}

Based on the findings of the Brazilian Oral
Health Status survey - SB Brasil - in 2003, ${ }^{4}$ the need to organize the providing of dental care procedures of medium complexity became evident, in order to meet the SUS (Unified National Health System) requirements. These data highlighted the severity of the oral health situation and also the precocity of dental loss, as well as the inequality prevailing in the access to dental services, which is the reality of almost $56 \%$ of the totally edentulous elderly. ${ }^{5}$

Based on these data, public health policies were developed according to the epidemiologic profile of the population and having integrality as a principle. Thus, the purpose of the "Brasil Sorridente" ${ }^{\text {pro- }}$ gram as an Oral Health National Policy is to correct distortions in the management of resources, carrying out effective new modes of action to assure greater access to oral health care, as well as to promote the qualifying of professionals to provide the health services offered by SUS.

Encouraging the construction of Dental Specialty Centers (CEOs) throughout the country is one of the strategies included in the municipal and regional health plans for each state. ${ }^{7}$

Dental Specialty Centers (CEOs) are oral health facilities of the SUS system which are part of the National Registry of Health Establishments (CNES) and are classified as Specialized Clinics or Specialty Ambulatories. The CEO is responsible for endodontic treatment, dental care for patients with special needs, minor oral surgery, periodontal treatment and oral diagnosis (focusing on oral cancer diagnosis), in addition to other specialties to be defined according to the needs of each area.

The first data regarding CEO installation and distribution showed 336 facilities, spread over 268 municipal districts in 25 states and in the Federal District (Table 1).

Until March 2008, 640 CEOs were installed all over the country, in 545 municipal districts (Graph 1).

The goal for 2010 is to have 950 CEOs working all over the country (source: National Oral Health Coordination $^{6}$ - MS, May 28, 2008).

In order to obtain the resources required for installation, 226 CEOs were accredited in advance. Between January 2005 and December 2006, more 
Table 1 - Number and distribution of CEOs among Brazil's administrative regions. Source: Ministry of Health, 2005.

\begin{tabular}{l|c}
\hline \multicolumn{1}{c|}{ Region } & Number of CEOs established \\
\hline Center-West & 33 \\
\hline Northeast & 104 \\
\hline North & 17 \\
\hline Southeast & 125 \\
\hline South & 57 \\
\hline Total & 336 \\
\hline
\end{tabular}

than 12.1 million dental procedures were performed in these centers.

The CEOs are one of the main actions of the "Brasil Sorridente" Program, and the treatment offered therein is a continuation of the work performed by the primary care network, which is also the case of the municipalities following the "Saúde da Família" (Family Health) Strategy, and is carried out by the oral health staff. 6,7

The Professionals of the primary care network are responsible for addressing patients' first needs, and then guiding them to the Dental Specialty Centers only when more complex procedures are required.

Each accredited Dental Specialty Center started to receive resources from the Ministry of Health, as per Ministry of Health regulation MS n. 1571 of July $29,2004 .^{7}$ A partnership among states, municipal districts and Federal Government is responsible for the implementation of the Specialty Centers: The Ministry of Health contributes with one share of the resources and the states and municipal districts contribute each one with the other shares.

Each CEO provides the specialized clinical care that the primary care facilities were unable to accomplish. The centers also have a dental prosthetic laboratory to do the laboratorial work required to provide prosthetic services, even for those provided at other dental facilities.

Regional Dental Prosthetic Laboratories (LRPDs) are establishments registered in the CNES (National Registry of Health Establishments) as Health Facilities to Support Diagnosis and Therapy (SADT). They are prepared to carry out procedures

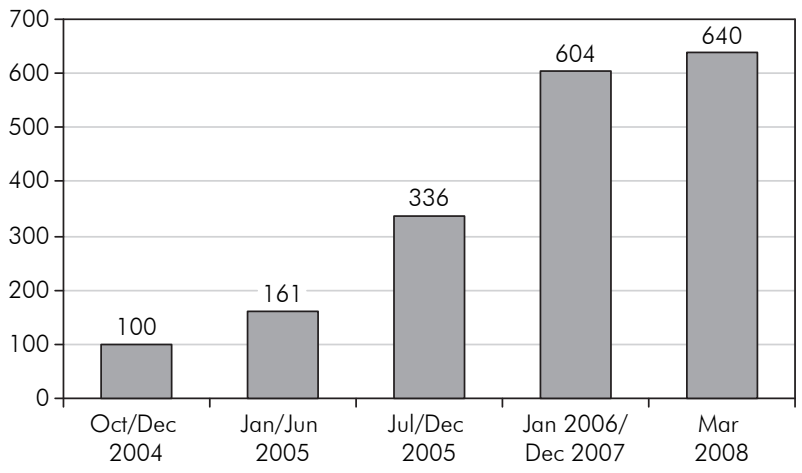

Graph 1 - Dental Specialty Centers established. Brazil, Oct/2004 - March/2008.

involving, at least, removable partial dentures and other acrylic denture services.

The laboratories can work adjoined to the CEOs, having a public nature, i.e. structured and managed by the municipal district, or work independently, having a private or even public nature. The main difference between the two kinds of LRPDs is that the facilities that work independently from the CEOs have to accomplish 40 removable partial denture procedures (cast metal framework) monthly.

The Human Resources team for the LRPD is constituted at least by 1 technician in dental prosthesis, or 1 dentist, working 40 hours a week, and dental prosthesis assistants.

The CEOs also offer appointments for oral diagnosis, focusing on the identification of oral cancer. This type of disease can be treated with successful rates, but $65 \%$ of all the identified cases are already in advanced stages. Every year, nearly 3 thousand people die from oral cancer in Brazil, while 30 million people have never gone to a dentist. ${ }^{4}$

Until the "Brasil Sorridente" Program was initiated by the government in March 2004, only 3.3\% of the dental care provided by the SUS (Unified National Health System) were specialized treatments. Before this period, almost every procedure involved primary care, such as dental extraction, dental amalgam restorations, topical fluoride application and composite restorations.

\section{Resources}

The Ministry of Health transfers funds of $\mathrm{R} \$ 40,000$ to build, increase, rebuild, and purchase 
both instruments and dental equipment for type I CEOs (three dental chairs), and $\mathrm{R} \$ 50,000$ for expenses with type II CEOs (four or more dental chairs). Furthermore, type I CEO managers receive $\mathrm{R} \$ 6,600$ per month for expenses, while type II CEO managers receive $\mathrm{R} \$ 8,800$ per month. For type III CEOs (minimum of seven dental chairs), the money destined for building or physical space suitability is $\mathrm{R} \$ 80,000$.

All citizens have the right to benefit from the services offered by the CEOs, but, if they want to use this service, they must first be seen by the primary care team, at health stations and basic health facilities. ${ }^{7}$

Patients cannot book an appointment at the centers by themselves. The health teams will assess the severity of the problems and then will book appointments for the patients at the specialty center. The health facilities continue the work performed by the professionals of the Family Health Program (PSF).

To register a CEO, a municipal or state manager must submit a proposal to the State Two-party Managerial Committee ("Comissão Intergestores Bipartite” - CIB). In the proposal, the type of CEO required (I, II or III) must be specified. The proposal must contain identification of the Municipal or State applicant and health facility, and a carbon copy must be submitted to the CNES, including a description of the services offered. It must comply with the Master Plan of Regionalization and indicate the CEO's range area. It should also indicate to which local authority, region or micro-region it will be assigned, and also the population it will give assistance to. A certificate, from managers, stating that all the infrastructure and resources requests meet the requirements of a Ministry of Health regulation (“Anexo I - Portaria GM/MS n 1.571, de 29 de julho de 2004") must also be submitted.?

The CIB then sends a request for registration to the Ministry of Health. Once it is accepted, the federal institution will issue a decree for the official registration. An LRPD registration is similar to that of a CEO. One of the requirements is that it observes the proportion of one LRPD to 100,000 inhabitants.

The Ministry of Health also provides resources to implement CEOs, as provided by a Ministry of
Health regulation ("Portaria GM/MS n' 283, de 22 de fevereiro de 2005). ${ }^{8}$

\section{Final considerations}

Conventional wisdom for many years was that caries was the main reason for tooth loss before age 35 , and periodontal disease was the main reason after age 35 . This belief was based on some old and rather dubious data. ${ }^{9,10}$

Even as late as 1978 there was a report that $8-10 \%$ of teeth are lost to periodontal disease by age 40 , and that such loss increases rapidly after that age. ${ }^{11}$

We are in agreement with Burt, Eklund ${ }^{12}$ (1999) that this historical picture has changed considerably in recent years. According to the authors, since the mid-1980s, studies from a number of countries and among different types of populations have consistently found that caries is the principal cause of tooth loss at most ages, with the possible exception of the oldest (i.e., those over 60 years).

In Brazil tooth loss is a serious public health problem, and the percentage of adults with total loss is high. A number of research studies have been carried out to determine the reasons for tooth loss ${ }^{13,14,15}$, all of which have shown tooth decay as the most important factor for tooth loss, followed by periodontal disease.

Educational level and age factors are associated to tooth loss. Tooth retention throughout the life course should be the main concern for both dental surgeons in general and all professionals working in public health services. ${ }^{15}$

In Brazil, less than $22 \%$ of the adult population and less than $8 \%$ of the elder people present healthy gum tissue. The data are from "SB Brasil 2003", the most complete oral health survey in the country. ${ }^{4}$

Furthermore, it is already possible to follow the impact of actions on oral health all over the country, especially regarding the reduction in the dental extraction indexes. Since 2002, about 2 million teeth were not extracted owing to these actions. This is an important health indication and it shows an improvement in the quality of oral health care in Brazil.

Water fluoridation, supervised toothbrushing, controlled fluoride mouthwash programs, use of sealant on pit and fissures, and early diagnosis and 
treatment of dental caries and periodontal diseases are all effective measures, but the oral health needs of a population are far more extensive than the ones mentioned here.

According to Leske et al. ${ }^{16}$ (1993), traditionally the prevention of oral diseases has been well-founded on three levels: i - primary prevention, related to the initiation of the disease; ii - secondary prevention, where the aim is to stop the progression of the disease and also disease recurrence; iii - tertiary prevention, where the goal is to avoid tooth loss (loss of function).

Statistics show that the Brazilian Government's Oral Health Program (within the SUS), with strong public oral health policies applied all over the country (see "Oral Health in Brazil - Part I: Public Oral Health Policies", also published in this issue), is an effective effort to reach the first prevention level. Two prevention levels, however, remain uncovered by the government's actions. The loss of teeth due to periodontal disease and/or to endodontic infections, and the replacement of the teeth by dental prostheses are still inaccessible to a great portion of Brazil's population, and only Dental Schools and few municipalities have had the resources to treat a small portion of those needs. ${ }^{17}$

Thus, the Dental Specialty Centers (CEOs) are a valid alternative to complement the population's needs all over the country. However, as Brazil has a continental dimension, great challenges still have to be overcome. In spite of the social policies undertaken and some favorable economic factors, more

\section{References}

1. World Health Organization. International Health Conference, New York, 19-22 June, 1946; signed on 22 July 1946 by the representatives of 61 States (Official Records of the World Health Organization, no. 2, p. 100) and entered into force on 7 April 1948.

2. Lindhe J, Karring T, Lang NP. Clinical periodontology and implant dentistry. $4^{\text {th }}$ ed. Oxford: Blackwell Munksgaard; 2003.

3. Bhuyan KK. Health promotion through self-care and community participation: elements of a proposed programme in the developing countries. BMC Public Health. 2004 Apr 16;4:11. centers and more specialists must still be better distributed over the country's different regions in order to achieve a better balance in oral care health to the population as a whole.

The closest program to that of the Brazilian Dental Specialty Centers (CEOs) is one developed in Cuba, ${ }^{12}$ but its data is not available for comparison.

Distribution of the CEOs all over the country should be proportional to the population size and oral health needs of each region. ${ }^{18}$ It is already possible to confront data from the first survey (2005, 336 CEOs) with that of the latest survey, still unpublished (2008, 640 CEOs). According to these data, an increase of $90.5 \%$ has been observed in the total amount of CEOs.

It will be a long journey, and more educational, preventive and also curative health measures must be taken in order to reach the Brazilian government's goal for $2010^{19}$, i.e. to have $90 \%$ of children aged 5-6 years free of dental caries, and with a DMFT index $<1$ at the age of 12 . But the program is working well, including tooth replacement by dental prosthesis, and it is very important for the population to have the possibility to treat their teeth with good quality, improving health and quality of life.

Based on the data presented here we conclude that public actions on oral health must involve both preventive and curative procedures in order to minimize distortions in the oral health of the populations of developing countries. To this end, the Dental Specialty Centers are a valid and welcome social program in Brazil.

4. Brasil. Ministério da Saúde. Secretaria de Atenção à Saúde. Departamento de Atenção Básica. Coordenação Nacional de Saúde Bucal. Projeto SB Brasil 2003: Condições de saúde bucal da população brasileira 2002-2003. Resultados Principais. Brasília; 2004.

5. Brasil. Ministério da Saúde. Secretaria de Atenção à Saúde. Departamento de Atenção Básica. Saúde Bucal/Ministério da Saúde, Secretaria de Atenção à Saúde, Departamento de Atenção Básica. Brasília: Ministério da Saúde; 2006. 92 p. il. Cadernos de Atenção Básica n. 17.

6. Brasil Sorridente. Ministério da Saúde. [cited 2008 May 28]. Available from: http://portal.saude.gov.br/saude/visualizar_texto.cfm?idtxt $=19578$. 
7. Brasil, Ministério da Saúde. Portaria $n^{\circ} 1.571$, de 29 de julho de 2004. Estabelece o financiamento dos Centros de Especialidades Odontológicas - CEO. [cited 2008 May 28]. Available from: http://dtr2004.saude.gov.br/susdeaz/legislacao/arquivo/63_Portaria_1571_de_29_07_2004.pdf

8. Brasil, Ministério da Saúde. Portaria n 283 GM de 22 de fevereiro de 2005. Antecipa do incentivo financeiro para Centros de Especialidades Odontológicas - CEO em fase de implantação, e dá outras providências. Available from: http://dtr2004.saude. gov.br/dab/docs/legislacao/portaria283_22_02_05.pdf.

9. Brekhus PJ. Dental disease and its relation to the loss of human teeth. J Am Dent Assoc. 1929;16:2237-47.

10. Pelton WJ, Pennel EH, Druzina A. Tooth morbidity experience of adults. J Am Dent Assoc. 1954;49:439-45.

11. Löe H, Ånerud A, Smith M. The natural history of periodontal disease in man. Tooth mortality rates before 40 years of age. J Periodontal Res. 1978;13:563-72.

12. Burt BA, Eklund SA. Dentistry, Dental Practice, and the Community. $5^{\text {th }}$ ed. Philadelphia: W. B. Saunders Company; 1999.
13. Caldas AF Jr., Marcenes W, Sheiham A. Reasons for tooth extraction in a Brazilian population. Int Dent J. 2000;50:26773.

14. Jovino-Silveira RC, Souza EHA, Caldas Jr. AF. Razões para extração de dentes permanentes. Odontologia Clín-Científ. 2002;1(3):207-10.

15. Jovino-Silveira RC, Caldas Jr. AF, Souza EHA, Gusmão ES. Primary reason for tooth extraction in a Brazilian adult population. Oral Health Prev Dent. 2005;3(3):151-7.

16. Leske GS, Ripa LW, Callane VA. Prevention of dental disease. In: Jong AW. Community Dental Health. $3^{\text {rd }}$ ed. London: Mosby; 1993. p. 156-96.

17. Pinto VG. Saúde Bucal Coletiva. $5^{\text {a }}$ ed. São Paulo: Santos; 2008.

18. Costa JFR, Chagas LD, Silvestre RM. A política nacional de saúde bucal do Brasil: registro de uma conquista histórica. Brasília: Organização Pan-Americana da Saúde; 2006. 67 p.

19. Pereira AC. Odontologia em saúde coletiva: planejando ações e promovendo saúde. Porto Alegre: Artmed; 2003. 